\title{
Gastric cancer with adenocarcinoma and yolk sac tumor components: A rare entity
}

\author{
Metin Yalaza, ${ }^{1}$ Mehmet Tolga Kafadar, ${ }^{2}$ Ahmet Turkan ${ }^{3}$ \\ ${ }^{1}$ Department of General Surgery, Division of Surgical Oncology, Numune Training and Research Hospital Ankara, Turkey \\ 2Department of General Surgery, Health Sciences University Mehmet Akif Inan Training and Research Hospital Sanlıurfa, Turkey \\ ${ }^{3}$ Department of General Surgery, Dr Munif Islamoglu State Hospital, Kastamonu, Turkey
}

\begin{abstract}
Despite a sharp worldwide decline in the incidence and mortality due to gastric cancer during the second half of the 20th century, gastric cancer remains the world's second leading cause of cancer-related deaths. Variants of gastric cancer account for approximately $5 \%$ of all stomach carcinomas. Herein, we report on a rare case of combined germ cell tumor and adenocarcinoma that arose in the stomach of a 68-year-old woman with a high level of alpha-fetoprotein in the serum. Clinical and pathological findings are presented.
\end{abstract}

Keywords: Adenocarcinoma; gastric cancer; germ cell tumors; yolk sac.

\begin{abstract}
Term cells tumors most frequently occur in the $J_{\text {gonads. Extragonadal localization is rare and }}$ concerns mainly midline locations such as the mediastinum, retroperitoneum, and pineal gland. Yolk sac tumor (YST) is a malignant tumor originating from the germ cell. Gastric adenocarcinoma with a yolk sac component is extremely rare with only a few cases reported in the literature [1].

Herein, we present a rare case of gastric cancer with adenocarcinoma and YST components in a 68-year-old woman who presented with metastatic para-aortic lymphadenopathy (LAP).
\end{abstract}

\section{CASE REPORT}

A 68-year-old woman presented with symptoms of appetite loss, weight loss, and abdominal pain that had persisted for 4 months. During a general health examination at a local clinic, para-aortic LAP was detected by abdominal tomography. Tru-Cut biopsy revealed adenocarcinoma with probable primary ovarian or other serosal origin. She was referred to our hospital for further evaluation and management. There was no significant physical findings. Except for anemia (level of hemoglobin: $11.1 \mathrm{~g} / \mathrm{dl}$ ), hematological and biochemical parameters were normal. The level of alpha-fetoprotein (AFP) in her serum was elevated to $50 \mathrm{ng} / \mathrm{mL}$ (normal: 0-32 ng/mL), whereas levels of carcinoembryonic antigen (CEA) (normal: $0-3 \mathrm{ng} / \mathrm{mL}$ ), and human chorionic gonadotropin (HCG) (normal: $0-10 \mathrm{mlU} / \mathrm{ml}$ ) in the serum were within the normal limits. Computed tomography of the abdomen showed gastric wall thickness at the lesser curvature of the mid body in

Received: October 06, 2016 Accepted: January 10, 2017 Online: October 17, 2017

Correspondence: Dr. Mehmet Tolga KAFADAR. Health Sciences University Mehmet Akif Inan Training and Research Hospital Clinic of General Surgery, Esentepe Mahallesi Ertugrul Caddesi, Sanlıurfa, Turkey.

Tel: +90 4143186000 e-mail: drtolgakafadar@hotmail.com

(c) Copyright 2017 by Istanbul Northern Anatolian Association of Public Hospitals - Available online at www.kuzeyklinikleri.com 

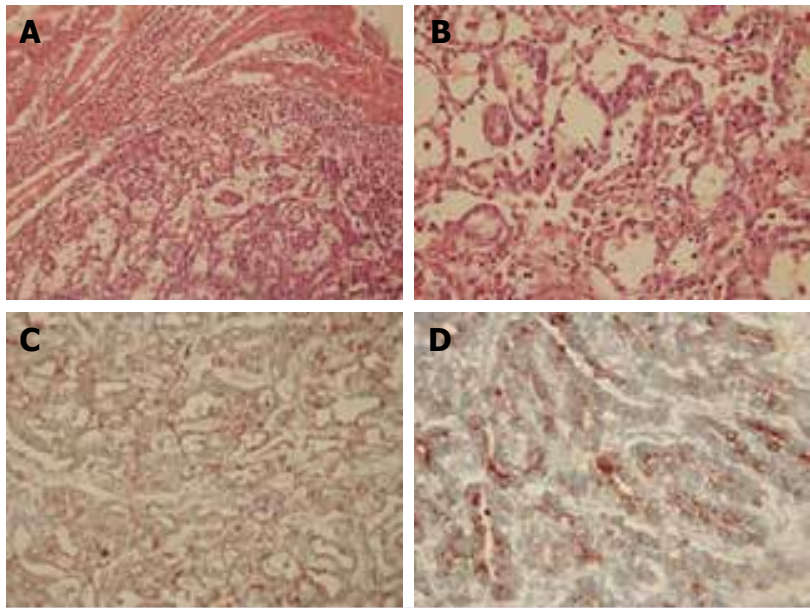

FIGURE 1. Morphological features of yolk sac tumor (A). Tumor with reticular pattern adjacent the gastric foveolar epithelium (B). Tumor cells, with pale eosinophilic cytoplasm and vesicular nuclei, appear to be arranged into microcystic and papillary or pseudopapillary structures. The tumor cells show immunoreactivity for cytokeratin (C) and for AFP (D).

addition to para-aortic lymph node enlargement. Upper digestive tract endoscopy showed a 5-6 cmulcerofungating mass in the lesser curvature of the gastric body. Histopathologic findings following gastroduodenoscopy revealed an invasive poorly differantiated adenocarcinoma. Total gastrectomy with D2 lymph node dissection and esophagojejunostomy were performed. Precise histopathological examination of resected specimens revealed the presence of a moderate-to-poorly differentiated invasive adenocarcinoma, with features of YST. An elevated tumor, $6 \times 5 \times 3 \mathrm{~cm}$ in size, with surface ulceration and hemorrhage was located in the antral minor curvature of the stomach. The tumor was primarily located in the mucosa and submucosa. The final diagnosis was T3, N3, M0, and stage III according to the Japanese classification of gastric cancer. Metastases to perigastric lymph nodes were also observed. The gastric tumor was composed of two histological types: YST and a moderately differentiated tubular adenocarcinoma. Majority of the tumor was occupied by a YST which showed the most common reticular pattern (Fig. 1A, B). Schiller-Duval bodies were also sporadically observed. Other com-

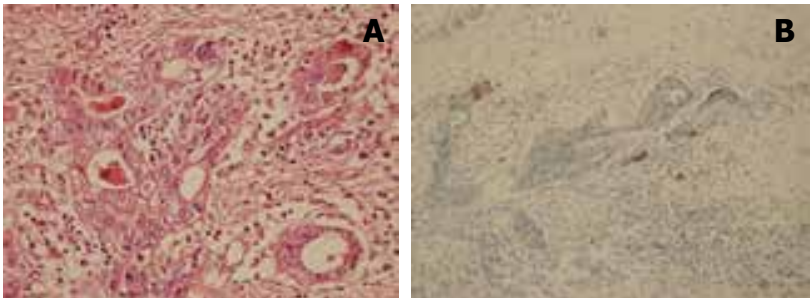

FIGURE 2. The adenocarcinomatous component of the tumor shows atypical tubular glands with luminal necrotic material (A). Focal AFP immunostaining in the adenocarcinoma component (B).

ponents of germ cell tumors, like embryonal carcinomas and choriocarcinomas, were not identified. In the yolk sac component, tumor cells showed immunoreactivity for cytokeratin (Fig. 1C) and AFP (Fig. 1D) but not for CEA, chromogranin A, cytokeratins 7 and 20, $\beta$-HCG , CDX2, placental alkaline phosphatase, and CD30. Focal staining for AFP was also observed in the adenocarcinoma foci (Fig. 2). Alternatively, CEA was strongly positive in the adenocarcinoma. The postoperative period was uneventful, and the patient was discharged on the 9 th postoperative day with a plan for chemotherapy. The patient died in 8 months after the surgery.

\section{DISCUSSION}

Gastric cancer remains one of the deadly diseases with poor prognosis. Sixteen cases of gastric YST have been reported in the medical literature since the description of the tumor in 1985 by Gharcia et al. (Table 1 ). It is notable that 11 cases $(68.75 \%$ ) have been reported to have adenocarcinoma components as well. The level of AFP in the serum was increased in most of these cases [2]. Six of the 16 patients with gastric YST had rapidly fatal clinical courses, consistent with the highly aggressive nature of these neoplasms at other sites. According to reported literature, gastric YST usually affect middleaged and elderly people with male preponderance, as confirmed by our case. They are aggressive neoplasms with early metastases. Five of the reported patients had long-term survival and one was a autopsy case. The remaining four patients had short survival times. The clinical presentation in most pa- 
TABLE 1. Summary of reported gastric yolk sac tumors

\begin{tabular}{|c|c|c|c|c|c|c|c|}
\hline Authors (year) & Age/Sex & Location & Tumor $(\mathrm{cm})$ & Therapy & Histology & Metastasis & Prognosis \\
\hline Garcia \& Ghali (1985) & $65 / M$ & Antrum & 5 & NT & $\mathrm{YST}, \mathrm{CC}, \mathrm{AC}$ & Liver & Autopsy case \\
\hline Motoyama (1985) & $72 / F$ & Body & $10.5 \times 9.5 \times 8.5$ & S & YST, AC & None & $\begin{array}{l}\text { Survival for } \\
3 \text { years }\end{array}$ \\
\hline Motoyama (1993) & $72 / \mathrm{F}$ & NM & $7 \times 6$ & & YST, AC, CC & None & Died in 3 years \\
\hline Zamecnik (1993) & $88 / \mathrm{M}$ & Antrum & NM & $\mathrm{s}$ & YST & $\begin{array}{l}\mathrm{LN} \text {, omentum, } \\
\text { retropyloric }\end{array}$ & Died in 4 weeks \\
\hline Suzuki (1999) & $56 / M$ & Cardia & $15 \times 10 \times 7$ & $\mathrm{~S}, \mathrm{CT}$ & YST, AC & $\begin{array}{l}\mathrm{LN} \text {, abdominal } \\
\text { cavity }\end{array}$ & Died in 6 weeks \\
\hline Puglisi (1999) & $61 / M$ & Antrum & 6 & NT & YST, AC & Abdominal cavity & Died in 1 month \\
\hline Wang (2000) & $36 / M$ & Body & NM & CT & YST, AC & $\begin{array}{l}\text { LN, lung, } \\
\text { spinal cord }\end{array}$ & Died in 6 months \\
\hline Napaki (2004) & $38 / F$ & E-G junction & NM & $\mathrm{S}, \mathrm{CT}$ & YST, AC & Liver & $\begin{array}{l}\text { Survived for } \\
32 \text { months }\end{array}$ \\
\hline Kanai (2005) & $87 / M$ & Cardia & $3 \times 3$ & S & YST & LN & Died in 7 months \\
\hline Singh (2007) & $67 / M$ & Body, antrum & $8 \times 10$ & $\mathrm{~S}, \mathrm{CT}$ & YST, AC & LN & Died in 2 months \\
\hline Hong (2007) & $50 / M$ & Antrum & $4.5 \times 3$ & $\mathrm{~S}$ & YST, AC & None & $\begin{array}{l}\text { Survived for } \\
12 \text { months }\end{array}$ \\
\hline Tahara (2008) & $74 / M$ & Body & $5 \times 3.5$ & NT & YST & LN, liver, O & Died in 6 days \\
\hline Gupta (2008) & $67 / M$ & NM & NM & $\mathrm{S}, \mathrm{CT}$ & YST, AC, CC & Liver, lung & $\begin{array}{l}\text { Death during } \\
\text { adjuvan } \mathrm{CT}\end{array}$ \\
\hline Kim (2009) & $61 / M$ & Body & $1 \times 0.8$ & S & YST & None & $\begin{array}{l}\text { No recurrence and } \\
\text { good condition for } 3 \\
\text { months after surgery }\end{array}$ \\
\hline Magni (2010) & $62 / M$ & Antrum & 7 & $\mathrm{~S}, \mathrm{CT}$ & YST & None & Died in 12 months \\
\hline Satake (2011) & 74/M & Body, antrum & $11 \times 8 \times 3$ & S, RFA, CT & YST, CC, AC & $\begin{array}{l}\mathrm{LN} \text {, liver, } \mathrm{O}, \\
\text { pancreas }\end{array}$ & $\begin{array}{l}\text { Recurrence in } \\
6 \text { months }\end{array}$ \\
\hline Present case & $68 / \mathrm{F}$ & Body & $5 \times 6$ & $\mathrm{~S}, \mathrm{CT}$ & $\mathrm{YS}, \mathrm{AC}$ & LN & Died in 8 months \\
\hline
\end{tabular}

YST: Yolk sac tumor; AC: Adenocarcinoma; CC: Choriocarcinoma; LN: Lymph node; O: Omentum; NM: Not mentioned; NT: No treatment; S: Surgery; CT: Chemotherapy; RFA: Radiofrequency ablation.

tients is remarkably uniform. YSTs of the stomach that have been reported to be large masses within the stomach. Although there has been at least one report of YST that did not respond at all to germ cell regimens, YSTs of the stomach should be treated with germ cell regimens, such as bleomycin, etoposide, and cisplatin or vinblastine, ifosfamide, and cisplatine. However, the adenocarcinomatous components may not be as responsive as the germ cell tumors. The disease tends to rapidly recur in spite of initial response to chemotherapy. Controversy remains regarding the origin of extragonadal germ cell tumors. These tumors can be found anywhere on the midline, particularly the retroperitoneum, an- terior mediastinum, sacrococcyx, and pineal gland. Other less common sites include the orbit, suprasellar area, palate, thyroid, submandibular region, anterior abdominal wall, stomach, liver, vagina, gallbladder, pancreas, and prostate [3]. The classic theory suggests that germ cell tumors in these areas are derived from migrating germ cells sequestered in the midline during embryogenesis [4]. This may be the case of pure YSTs occurring in the stomach [5-8]. An alternative theory suggests that the tumor originates due to aberrant differentiation of somatic cells $[9,10]$. This might explain cases of YST occurring in the stomach or lung. Aberrant differentiation of adenocarcinomas may explain the devel- 
opment of gastric YST with a adenocarcinomatous component, as observed in the present case.

\section{CONCLUSION}

In patients with gastric carcinoma with a high level of AFP in the serum, YST is the likely diagnosis. Although the reported number of gastric adenocarcinomas with a yolk sac component is not so large to predict a proper outcome, the presence of the yolk sac component may be an indication of poor prognosis in terms of duration of survival.

Conflict of Interest: No conflict of interest was declared by the authors.

Financial Disclosure: The authors declared that this study has received no financial support.

Authorship contributions: Concept - M.Y., M.T.K.; Design M.Y., M.T.K., A.T.; Data Collection - M.Y., A.T.; Analysis - M.Y., M.T.K. A.T., Literature search - M.Y., M.T.K.; Writing - M.Y., M.T.K.

\section{REFERENCES}

1. Suzuki T, Kimura N, Shizawa S, Yabuki N, Yamaki T, Sasano H, et al. Yolk sac tumor of the stomach with an adenocarcinomatous component: a case report with immunohistochemical analysis. Pathol Int 1999;49:557-62. [CrossRef]

2. Motoyama T, Saito K, Iwafuchi M, Watanabe H. Endodermal sinus tumor of the stomach. Acta Pathol Jpn 1985;35:497-505.

3. Satake N, Chikakiyo M, Yagi T, Suzuki Y, Hirose T. Gastric cancer with choriocarcinoma and yolk sac tumor components: case report. Pathol Int 2011;61:156-60. [CrossRef]

4. Puglisi F, Damante G, Pizzolitto S, Mariuzzi L, Guerra S, Pellizzari L, et al. Combined yolk sac tumor and adenocarcinoma in a gastric stump: molecular evidence of clonality. Cancer 1999;85:1910-6. [CrossRef]

5. Magni E, Sonzogni A, Zampino MG. Primary pure gastric yolk sac tumor. Rare Tumors 2010;2:e10. [CrossRef]

6. Zámecník M, Patriková J, Gomolcák P. Yolk sac carcinoma of the stomach with gastrin positivity. Hum Pathol 1993;24:927-8.

7. Kanai M, Torii A, Hamada A, Endo Y, Takeda Y, Yamakawa M, et al. Pure gastric yolk sac tumor that was diagnosed after curative resection: case report and review of literature. Int J Gastrointest Cancer 2005;35:77-81. [CrossRef]

8. Kim YS, Kim SH, Seong JK, Lee BS, Jeong HY, Song KS. Gastric yolk sac tumor: a case report and review of the literature. Korean J Intern Med 2009;24:143-6. [CrossRef]

9. Garcia RL, Ghali VS. Gastric choriocarcinoma and yolk sac tumor in a man: observations about its possible origin. Hum Pathol 1985;16:955-8. [CrossRef]

10. Wang L, Tabbarah HJ, Gulati P, Rice S, French SW. Gastric adenocarcinoma with a yolk sac component: a case report and review of the literature. J Clin Gastroenterol 2000;31:85-8. 